Original Article

\section{Assessment of antibacterial potential of natural and commercial honey samples against wound isolates.} Zareen Fatima, Sidra Zafar \& Tuba Batool

Department of Microbiology, Jinnah University for Women, Karachi, Pakistan

OPEN

ACCESS
Doi: 10.29052/IJEHSR.v8.i3.2020.123-128

Corresponding Author Email:

Sidrazfr@gmail.com

Received 26/03/2020

Accepted 24/08/2020

First Published 01/09/2020

\section{(c) (i)}

(C) The Author(s). 2020 Open Access This article is distributed under the terms of the Creative Commons Attribution 4.0 International License (http://creativecommons.org/licenses/by/4.0/)

\title{
Abstract
}

Background: Antibiotic resistance has surged the development and exploration of new, improved and effective natural products from plants and other sources like honey, which has been rediscovered as a therapy for wounds, both in-vitro studies and in clinical trials. It has been observed to exert bacteriostatic and bactericidal potentials against pathogenic bacteria, including drug-resistant strains. The following study aimed to isolate and identify bacteria from wound infections and to investigate the antibacterial activity of honey samples; natural and commercial honey, against common clinical wound Pathogens.

Methodology: Bacteria from wound samples of patients with injured legs were isolated using differential and selective agars, while the antibacterial activity of natural and commercial honey samples was determined by agar well diffusion method and Minimum Inhibitory Concentrations (MIC).

Results: The results indicated that natural honey has more potential to exert antibacterial activity with an 18$30 \mathrm{~mm}$ zone of inhibition, which was significantly higher as compared to commercial honey with a 13-23 mm zone of inhibition. MIC of natural honey was visible in most of the test organisms at $25 \mu \mathrm{g} / \mathrm{ml}$ as compared to commercial honey with only Bacillus sp and Staphylococcus sp2 at $50 \mu \mathrm{g} / \mathrm{ml}$ while Staphylococcus sp1 at $25 \mu \mathrm{g} / \mathrm{ml}$.

Conclusion: The results proposes due to a significant difference in the antibacterial activity of natural and commercial honey, these findings would help experts from the health sciences in the selection of the type of honey as an apitherapy for wound care and management.

\section{Keywords}

Honey, Antibacterial Activity, Drug-Resistant, Minimum Inhibitory Concentration, Agar Well Diffusion Method, Apitherapy.

\section{Check for updates}




\section{Introduction}

Natural honey is famous for its nutraceutical properties, as it is mainly composed of sugars, including fructose, glucose, sucrose, and maltose. However, oligosaccharides, proteins, minerals, vitamins, polyphenols and other trace elements may also be present. Pharmacologic effects of honey, i.e. antimicrobial, immunomodulatory, prebiotic, antinematodal, anti-inflammatory, and antinociceptive activities, have been reported in various studies with a bacteriostatic and bactericidal effect against resistant pathogens ${ }^{1-3}$. It has been used for medicinal purposes for many years, which has been confirmed by many clinical studies for skin burns, ulcers and wound ${ }^{4-8}$. It boosts the immune system and stimulates regeneration of wounds. Investigations into the microbial flora of wounds began in the late 19th century. Since then, there have been various improvements made in techniques in order to facilitate the recovery, identification and enumeration of a wide variety of microbial species. Most wounds are colonized with relatively stable polymicrobial communities, often without signs of infection ${ }^{9,10}$. However, potential pathogens may be present that can disrupt the balance between host responses and microorganism ${ }^{11}$. Wound infection causes damaging effects to patients with increased pain, discomfort and inconvenience and could be fatal if not treated properly on time. Disruption in the balance between complex host and microbial interplay affects the healing process and might increase the hospital stays and treatment costs ${ }^{12}$. Antimicrobial agents are important in reducing the global burden of infectious diseases ${ }^{13,14}$. However, the occurrence of drug-resistance has reduced the development of antibiotics and poses a big challenge as few pharmaceutical companies remain active in this area ${ }^{15}$. The failure of such antibiotics has surged the development and exploration of new, improved and effective natural products from plants and other sources ${ }^{16,17}$. Antibacterial activity of honey was first recognized in 1892; however, due to lack of scientific support, it has limited use in modern medicine ${ }^{18}$, which has lately been rediscovered as a therapy for wounds ${ }^{19}$. Interest in this approach stems partly from the emergence of antibiotic-resistant pathogens.
Antimicrobial properties of honey have been reported in various studies, but the mechanisms by which it acts are not completely understood.

Strong solutions of honey and sugar pastes are thought to inhibit microbial growth because of their high osmolarity. Honey exerts its antimicrobial potential either through hydrogen peroxide and other enzymatic activity or through flavonoids present in the honey of floral source. Discovery of antibiotics had declined the trend of using folk medicine, but antibiotic resistance has resurrected folk medicinal usage both in-vitro studies and in clinical trials ${ }^{20}$. Hence the following study aimed to isolate and identify bacteria from wound infections and to investigate the antibacterial activity of honey against common clinical wound Pathogens.

\section{Methodology}

The study was conducted at Jinnah University for women, Department of Microbiology. 20 Wound samples from patients with injured legs were collected using sterile swab stick from different hospitals in Karachi. Written permission in the form of informed consent was taken from individual participants. No personal identity of participants was revealed. No participant was forced to take part in research work. All the information was treated with confidentiality.

\section{Isolation \& Identification}

Differential and selective agars, i.e. Eosin Methylene Blue (EMB), Mannitol Salt Agar (MSA), Pseudo agar and Blood agar, were used for the isolation of bacteria. However, for the identification of isolates, preliminary screening methods were used, including gram staining TSI, SUGAR TEST, CATALASE and Sensitivity Testing.

\section{Antibacterial Activity of Honey}

Two samples of honey, i.e. commercially prepared and natural honey were used. Antibacterial activity was determined using the following methods;

\section{Agar Well Diffusion Method}

- Honey samples were preheated in order to reduce the Viscosity. 
- Muller Hinton Agar (MHA) was used for sensitivity testing.

- Test organisms were inoculated on the MHA using the spread plate method separately.

- Wells were made on each plate using a sterile borer.

- $\quad 50 \mu$ l of the honey samples were placed in each well, and the plates were allowed to stay for a few minutes for pre diffusion to take place, followed by incubation of $24-48 \mathrm{hrs}$ at $37^{\circ} \mathrm{C}$.

- The zones of inhibition were measured with the use of a caliper/ruler.

\section{MIC (Minimum Inhibitory Concentration)}

MICs of honey for the wound isolates were determined using the broth dilution method.

- A stock solution of $50 \%$ honey was prepared in sterile de-ionized water.
- $2 \mathrm{ml}$ of nutrient broth was pipetted into six tubes.

- Subsequently, $2 \mathrm{ml}$ stock solution was transferred to the tube with nutrient broth to prepare a twofold serial dilution.

- $100 \mu \mathrm{l}$ of an overnight culture of test organisms was added in each tube.

- After 24 hrs incubation, each tube was examined for the presence and absence of turbidity to indicate the growth of the microorganism.

\section{Result}

Among the isolates obtained, five were observed to be sensitive to honey samples. The antibacterial activity of honey samples is elaborated in Tables 2 and 3, whereas biochemical identification is presented in Table 1.

Table 1: Biochemical Identification of Isolates

\begin{tabular}{|c|c|c|c|c|c|c|}
\hline \multirow{2}{*}{ Strain } & \multirow{2}{*}{ Gram Stain } & \multicolumn{4}{|c|}{ Sugar test } & \multirow{2}{*}{ Catalase } \\
\hline & & Glucose & Sucrose & Mannose & Lactose & \\
\hline Bacillus sp. & Gram + ve rods & + ve & $+v e$ & $+v e$ & -ve & $+v e$ \\
\hline $\begin{array}{l}\text { Staphylococcus } \\
\text { sp1 }\end{array}$ & $\begin{array}{l}\text { Gram +ve cocci } \\
\text { (clusters) }\end{array}$ & + ve & $+v e$ & $+v e$ & $+v e$ & $+v e$ \\
\hline $\begin{array}{l}\text { Staphylococcus } \\
\text { sp2 }\end{array}$ & $\begin{array}{l}\text { Gram +ve cocci } \\
\text { (clusters) }\end{array}$ & + ve & $+v e$ & $+v e$ & $+v e$ & $+\mathrm{ve}$ \\
\hline \multirow{2}{*}{ Strain } & \multirow{2}{*}{ Gram Stain } & \multicolumn{4}{|c|}{ TSI } & - \\
\hline & & Butt & Slant & Gas & H2S & - \\
\hline E.coli & Gram -ve rods & Acid & Acid & +ve & -ve & + ve \\
\hline Pseudomonas sp. & Gram -ve rods & Alkaline & Alkaline & -ve & -ve & + ve \\
\hline
\end{tabular}

Table 2: Agar Well Diffusion Method

\section{Commercial HONEY}

Test organisms

Antibacterial Test organisms
activity
(zone of
inhibition)

Natural HONEY
Bacillus sp.

Bacillus sp. $23 \mathrm{~mm}$

Staphylococcus sp1

Staphylococcus sp2

E. coli

Pseudomonas sp.
$15 \mathrm{~mm}$

$13 \mathrm{~mm}$

$0 \mathrm{~mm}$

$0 \mathrm{~mm}$
Staphylococcus sp1

Staphylococcus sp2

E.coli

Pseudomonas sp.

\section{Antibacterial activity (zone of} inhibition) $30 \mathrm{~mm}$ $20 \mathrm{~mm}$ $18 \mathrm{~mm}$ $20 \mathrm{~mm}$ 
Table 3: MIC (Minimum Inhibitory Concentration)

\begin{tabular}{|c|c|c|c|c|c|c|c|c|c|c|c|c|c|}
\hline \multicolumn{7}{|c|}{ Commercial HONEY } & \multicolumn{7}{|c|}{ Natural HONEY } \\
\hline \multirow[t]{2}{*}{ Test organisms } & \multicolumn{6}{|c|}{$M I C(\mu \mathrm{g} / \mathrm{ml})$} & \multirow[t]{2}{*}{ Test organisms } & \multicolumn{6}{|c|}{ MIC $(\mu \mathrm{g} / \mathrm{ml})$} \\
\hline & $\begin{array}{l}10 \\
0\end{array}$ & $\begin{array}{l}5 \\
0\end{array}$ & $\begin{array}{l}2 \\
5\end{array}$ & $\begin{array}{l}12 . \\
5\end{array}$ & $\begin{array}{l}6.2 \\
5\end{array}$ & $\begin{array}{l}3.12 \\
5\end{array}$ & & $\begin{array}{l}10 \\
0\end{array}$ & $\begin{array}{l}5 \\
0\end{array}$ & $\begin{array}{l}2 \\
5\end{array}$ & $\begin{array}{l}12 . \\
5\end{array}$ & $\begin{array}{l}6.2 \\
5\end{array}$ & $\begin{array}{l}3.12 \\
5\end{array}$ \\
\hline Bacillus sp. & - & - & + & ++ & ++ & ++ & Bacillus sp. & - & - & + & ++ & ++ & ++ \\
\hline $\begin{array}{l}\text { Staphyloco } \\
\text { ccus sp1 }\end{array}$ & - & - & - & + & ++ & ++ & $\begin{array}{l}\text { Staphyloco } \\
\text { ccus sp1 }\end{array}$ & - & - & - & ++ & ++ & ++ \\
\hline $\begin{array}{l}\text { Staphyloco } \\
\text { ccus sp2 }\end{array}$ & - & - & + & + & ++ & ++ & $\begin{array}{l}\text { Staphyloco } \\
\text { ccus sp2 }\end{array}$ & - & - & - & ++ & ++ & ++ \\
\hline E. coli & + & + & $\begin{array}{l}+ \\
+\end{array}$ & ++ & ++ & ++ & E. coli & - & - & - & ++ & ++ & ++ \\
\hline $\begin{array}{l}\text { Pseudomo } \\
\text { nas sp. }\end{array}$ & + & + & $\begin{array}{l}+ \\
+\end{array}$ & ++ & ++ & ++ & $\begin{array}{l}\text { Pseudomo } \\
\text { nas sp. }\end{array}$ & - & - & - & ++ & ++ & ++ \\
\hline
\end{tabular}

${ }^{\star}(++)$ High turbidity $(+)$ low turbidity (-) No turbidity

*The pattern of sensitivity was determined using different concentrations of honey. Tubes with less turbidity and no visible growth of microorganisms were considered as the minimum inhibitory concentrations.

\section{Discussion}

The rapid surge of Pathogenic and resistant microorganisms with only a few effective antibiotics and an increase in disease burden have shifted the interests towards 'alternative medicine' such as natural remedies, especially towards apitherapy ${ }^{21,22}$. Honey is known for its regenerative properties, with no scar formation. Hygroscopicity, hypertonicity, lower $\mathrm{pH}$ and complex chemical composition are the main factors that participate in exerting its activity. It serves as broad-spectrum antimicrobial agents. Recently, 60 species were identified to be sensitive with honey ${ }^{21,23}$ where pure honey was reported to be bactericidal to many pathogenic microorganisms, including Salmonella, Shigella, Escherichia coli, Vibrio cholera ${ }^{21}$.

In the following study, two samples of honey were tested to compare their antimicrobial activity against the bacterial isolates obtained from wound infection. Agar well diffusion method with commercial honey showed antibacterial activity against most of the isolates with a zone of inhibition between 13-23 mm, whereas natural honey was effective against all the isolates with 18$30 \mathrm{~mm}$ zone of inhibition as presented in table 2 . However, according to Khalil et al., all undiluted honey samples (100\%) showed significant antibacterial activity against the test strains ${ }^{24}$. Similarly, Hamza et al., in 2015, demonstrated undiluted honey with $25.38 \mathrm{~mm}$ zone of inhibition against $\mathrm{S}$. aureus ${ }^{25}$, which is in contrast to our results with the larger zone $(18-20 \mathrm{~mm})$ observed from natural honey against $\mathrm{S}$. aureus strain. While in 2019, Bunza reported the significant antibacterial activity of honey at $100 \%$ and $50 \%$ with S. aureus, P. aeruginosa and E.coli test organisms ${ }^{26}$. More recently, Ifra et al., have demonstrated in 2020 that the antibacterial activity of honey depends on concentration as well as the nature of the test organisms by using different samples of honey tested at three different concentrations against wound isolates ${ }^{27}$.

The antibacterial activity of honey samples was further evaluated through MIC at concentrations ${ }^{3}$. $125-100 \mu \mathrm{g} / \mathrm{ml}$, as shown in table 3. Natural honey showed significant MIC at $25 \mu \mathrm{g} / \mathrm{ml}$, visible in most of the test organisms as compare to commercial honey with only Bacillus sp and Staphylococcus sp2 with MIC at $50 \mu \mathrm{g} / \mathrm{ml}$ while Staphylococcus sp1 at $25 \mu \mathrm{g} / \mathrm{ml}$. Considering the resistant pattern of Staphylococcus ${ }^{28,29}$, these results demonstrate that staphylococcus is more susceptible to honey than other test isolates, which is similar to the results presented by Halima et al., in 2020 that Staphylococcus aureus was most sensitive 
organism isolated with MIC consistent at $20 \%{ }^{30}$. Similarly, Molanaei et al., tested Methicillinresistant staphylococcus strains against the honey samples and demonstrated the MIC of resistant strains at $<8 \%$ concentration. Therefore following results suggest that honey is highly potent against the pathogenic bacteria, especially against antibiotic-resistant staphylococcus ${ }^{31}$. Thus natural honey is an essential antibacterial agent that could inhibit the resistant bacteria at low concentration. Further, it can be concluded from these results that in comparison with commercial honey, natural honey has more potency for antibacterial activity. However, variations in the antibacterial activity of honey depend on various factors, including the plant source, environment; even honey collected from a single location can have variation in antibacterial activity and the concentration of honey used, higher the concentration, greater the antibacterial activity ${ }^{32,33}$.

Due to the lack of funding and financial constraints, standard controls were not used. A short monitoring period has also limited further molecular testing of the isolates and wound application to monitor the regenerative property. Therefore further research with a longer time duration is required to overcome these limitations.

\section{Conclusion}

Overall these finding suggests that there is a significant difference in the antibacterial activity of natural and commercial honey with distinct osmolality, $\mathrm{pH}$, peroxide and non-peroxide components that possibly exert antibacterial effects against the wound isolates. As a rediscovered alternate medicine, with no toxicity and low cost, it needs further molecular testing of the isolates and characterization of the active bactericidal components to monitor the regenerative property. These findings would help health professionals in the assortment of the type of honey as an apitherapy, inpatient care and management of wounds.

\section{Conflicts of Interest}

None.

\section{Acknowledgement}

The authors acknowledge academic staff for their valued cooperation during the research conduct for completion of the study.

\section{Funding}

None.

\section{References}

1. Sajid $M$, Azim MK. Characterization of the nematicidal activity of natural honey. J Agric Food Chem. 2012; 60: 7428-7434.

2. Mesaik MA, Azim MK, Mohiuddine S. Honey modulates oxidative burst in professional phagocytes. Phytother Res. 2008; 22: 1404-1408.

3. Azim MK, Perveen $H$, Mesaik MA, Simjee SU. Antinociceptive activity of natural honey in thermalnociception in mice. Phytother Res. 2007; 21:194-197.

4. Asamoah B, Ochieng B, Meetoo D, is Resident BA. The clinical role of honey in treating diaebtic foot ulcers: a review. Diabetic Foot Can. 2014; 2(2):30-34.

5. Holland L, Norris J. Medical grade honey in the management of chronic venous leg ulcers. Int I Surg 2015; 20(4):17-20.

6. Jull $A B$, Cullum $N$, Dumville $J C$, Westby MJ, Deshpande S, Walker N. Honey as a topical treatment for wounds (Review). Cochrane Database Syst Rev 2015; 3(CD005083).

7. Watts R, Frehner E. Evidence Summary: wound management: medical-grade honey. Wound Pract Res. 2017; 24(1):61-64.

8. Boateng J, Catanzano O. Advanced therapeutic dressings for effective wound healing: a review. J Pharm Sci. 2015; 104(11):3653-3680.

9. Oryan A, Alemzadeh E, Moshiri A. Biological properties and therapeutic activities of honey in wound healing: a narrative review and metaanalysis. J Tissue Viability. 2016; 25(1):1-2

10. Bowler PG, Duerden BI, Armstrong DG. Wound microbiology and associated approaches to wound management. ClinMicrobiol Rev. 2001; 14(2): 244269.

11. Hansson CJ, Hoborn J, Moller A, Swanbeck G. The microbial flora in venous leg ulcers without signs of clinical infection. Acta Derm-Venereol. 1995; 75: 2430. 
12. Emmerson M. A microbiologist's view of factors contributing to infection. New Horiz. 1998; 6(2): (Suppl.), S3-S10.

13. O'Meara SM, Cullum NA, Majid M. Sheldon TA. Systemic review of antimicrobial agents used for chronic wounds. Brit J Surg, 2001; 88: 4-21.

14. Shears $P$. Antimicrobial resistance in the tropics. Trop Doct. 2000; 30(2): 114-116.

15. Mulu A, Tessema B, Derbie F. In vitro assessment of the antimicrobial potential of honey on common human pathogens. Ethiop J Health Dev. 2005; 18(2): 107-111.

16. Bansal V, Medhi B, Pandhi P. Honey-a remedy rediscovered and its therapeutic utility. Kathmandu Univ Med J. 2005; 3(3): 305-309.

17. Omoya F, Akharaiyi F. Mixture of honey and ginger extract for antibacterial assessment on some clinical isolates. Int J Pharm Bio Res. 2011; 2(1), 39-47.

18. Dixon B. Bacteria can't resist honey. Lancet Infect Dis. 2003; 3(2): 116.

19. Mohapatra DP, Thakur V, Brar SK. Antibacterial efficacy of raw and processed honey. Biotechnology Research International. 2011; Article ID 917505, 6 pages.

20. Viuda - Martos M, Ruiz - Navajas Y, Fernández López J, Pérez - Álvarez JA. Functional properties of honey, propolis, and royal jelly. J food sci. 2008; 73(9): R117-124.

21. Samarghandian S, Farkhondeh T, Samini F. Honey and Health: A Review of Recent Clinical Research. Pharmacogn Res. 2017; 9: 121-127.

22. Aurongzeb M, Azim MK. Antimicrobial properties of natural honey: a review of literature. Pak J Biochem Mol Biol. 2011; 44(3): 118-124.

23. Abeshu MA, Geleta B. Medicinal uses of honey. Biol Med (Aligarh) 2016; 8(2): 279.

24. Khalil AT, Khan I, Ahmad K, Khan YA, Khan J, Shinwari ZK. Antibacterial activity of honey in northwest Pakistan against select human pathogens. J Tradit Chin Med. 2014; 34(1): 86-89.

25. Hamza AS, Aliyu A, Ibrahim FM. Evaluation of antibacterial activity of Sudanese bee honey against four species of bacteria. Am J Res Commun. 2015; 3(4): 132-142.

26. Bunza NM, Kumurya AS, Isah AA, Azeez BA, Nafiu F. Comparative Evaluation of the Antibacterial Effects of Honey with Standard Antibiotic on Bacterial Isolates from Wound Infection. Asian J Res Med Pharm Sci. 2019; 1-7.
27. Nur IT, Jahan T, Akter S. Isolation of pathogenic microorganisms from burn patient and in vitro determination of antibacterial activity of honey against antibiotic resistance isolates. International Journal. 2020;6(8):310.

28. Foster TJ. Antibiotic resistance in Staphylococcus aureus. Current status and future prospects. FEMS Microbiology Rev. 2017; 41(3): 430-449.

29. Rağbetli C, Parlak M, Bayram Y, Guducuoglu H, Ceylan N. Evaluation of antimicrobial resistance in Staphylococcus aureus isolates by years. Interdisciplinary Perspectives Infect Dis. 2016.

30. Isa $H$, Sa'id AS, Adaora OJ. Evaluation of Antibacterial Activity of Different Honey samples on Staphylococcus aureus, Klebsillapneumoniae and Escherichia coli Isolated from Wounds. Science. 2020; 5(1):107-111.

31. Molanaei A, Seyedoshohadaei SA, Hasani S, Sharifi P, Rashidian M, Taherpour A, TozandehJani S. Evaluation of the sensitivity of Staphylococcus aureus isolated from nasal swabs to natural honey. Sudan Journal of Medical Sciences. 2020;15(1):5664.

32. Mandal MD, Mandal S. Honey: its medicinal property and antibacterial activity. Asian Pac J Trop Biomed. 2011; 1(2): 154-160.

33. Raju VN, Goli D. In-vitro comparative antimicrobial activity of commercial and raw honey against various bacteria isolated from ear discharges. Acad J Pharm. 2013; 2(1):5-11 